\title{
INNOVATING APART OR TOGETHER: LITHUANIAN FARMERS AND RURAL COMMUNITIES
}

\author{
Rita Vilkè, Dalia Vidickienè, Živilè Gedminaitė-Raudonė \\ Lithuanian institute of agrarian economics, Lithuania \\ rita.vilke@laei.lt; dalia.vidickiene@laei.lt; zivile.gedminaite@laei.lt
}

\begin{abstract}
The changing economic and social situation in the regions leads to the changing understanding of the potential which exists in the countryside. This research is based on the idea that farmers operate in close neighbourhood with the local communities and therefore they may hold a potential to start innovation processes in rural regions as agents of change. This may happen individually or together with the local community. Farmers are active in acquiring new knowledge and experience through collaboration with advanced innovation centres in research laboratories and universities, and sharing with the local community, thus making these innovations open. The success of innovators comes in line with the collaboration and therefore the defined three key factors of 'innovating together' in this research are: first, the shift from technical to organizational innovations; second, the shift from sectorial to territorial rural development strategies; third, the size of farms and rural enterprises due to the limited number of employees. Theoretical findings are followed by empirical investigations from representative data collected in Lithuanian farms in 2017, supported with relevant statistical analysis. Research results show that the potential for 'innovating together' in Lithuanian farms is rather weak when taking into account all three factors. However, there are reasons behind this which give insights for future developments in the field.
\end{abstract}

Key words: innovation, collaboration, farmer, local community, rural development.

\section{Introduction}

The current economic and social situation in rural regions is guiding the rural population towards the creation of new perceptions of farming and rural life that are totally different from the perceptions in the era of industrialization of agriculture. In such conditions the success is most often defined by the ability to innovate (Chrisman et al., 2015; Dunne et al., 2016; Kusano, Wright, \& Conger, 2016). Farmers that focus on innovation as a core value are finding success in business (Madureira et al., 2015; Reimers-Hild \& Dye, 2015a; Reimers-Hild \& Dye, 2015b; Neumeier, 2017; etc.). Innovative rural communities are creating better quality of life (Pittaway et al., 2004; Vaccaro et al., 2012; Esparcia, 2014; Lambrecht et al., 2015; Salemink, Strijker, \& Bosworth, 2017). However, a lot of innovative initiatives fail and there are numbers of reasons behind that (von den Eichen, Freiling, \& Matzler, 2015).

The extensive review and systematization of scientific literature focusing on the innovative activities in the context of rural development shows that the success of innovators comes in line with collaboration. Therefore, authors proposed the existence of three key factors that call for innovating together, namely:

1. the shift from technical to organizational innovations;

2. the shift from sectorial to territorial rural development strategies;

3. the size of farms and rural enterprises due to the limited number of employees.

Recent findings demonstrate that technical innovations have been dominant since the middle of the last century. Griffin (2013) states that 'many of the most important innovations over the last 50 years have been technical' (p. 206). Most of them have been created by scientists and have provided technological solutions for a process or product which are new on a national or global level. The role of farmers used to be understood as implementers of the technical innovation only, since the initiators and designers of innovations used to be outsiders.

During the last decades, the shift from technical to organizational innovations has become evident (Griffin, 2013; Chrisman et al., 2015; Kusano, 2016). Its main ideas take into account changes in the managerial and marketing processes in farming, as well. Dynamic business environment and the variety of roles to be fulfilled by modern multifunctional farm require focusing on organizational innovations (Vaccaro et al., 2012; Creaney, McKee, \& Prager, 2014; Salemink, Strijker, \& Bosworth, 2017). Some scientific discussions have raised the issue of servitization of rural economy, which demands a lot of organizational innovations to be implemented (Jean, 2014; Salemink, Strijker, \& Bosworth, 2017; Vidickienè, 2017).

The shift from sectorial to territorial rural development strategies has resulted in a stronger focus on endogenous factors of development (Creaney, McKee, \& Prager, 2014; Zago et al., 2015). However, the current challenges faced by agriculture and farming cover only a small part of the rural development issues. Rural communities encounter the need to solve a range of new social problems (Esparcia, 2014; Jean, 2014; Madureira et al., 2015; Salemink, Strijker, \& Bosworth, 2017). Imitation of urban models as the apotheosis of qualitative life does not work in the 21 st century. The goal of modern innovators is to 
use local cultures and know-how as key assets for rural development in a different way compared to the development of urban settlements.

The size of a farm and rural enterprise due to the number of employees in most cases is defined as a limiting factor to innovation (Creaney, McKee, \& Prager, 2014; Esparcia, 2014; von den Eichen, Freiling, \& Matzler, 2015; Dunne et al., 2016). This restricts the potential of local inhabitants to search for and collect innovation-related information, their possibility to exchange knowledge with colleagues, discuss new important trends and to collaborate in cooperative innovation projects (Vacaro et al., 2012; Lambrecht et al., 2015).

Networking is perceived as an important strategic tool in attaining innovation. It is beneficial to capture ideas, reduce distance with policy makers, prevent them from insulation, know the right people and places to obtain information (Lambrecht et al., 2015; Madureira et al., 2015). Networks give access to complementary resources, skills, capabilities, and knowledge that are not internally available (Pittaway et al., 2004; Vacaro et al., 2012). Knowledge networking and multi-actor knowledge networks that facilitate knowledge exchanges, joint learning and the generation of new, more integrated solutions, are crucial if the agriculture is to become sustainable and resilient (Šumane et al., 2017). In order to achieve innovation, a wide range of network partners can be used, such as colleagues, input industries, traders, researchers, extensionists, government officials, civil society organizations, etc. (Pittaway et al., 2004; Vacaro et al., 2012; Lambrecht et al., 2015; Madureira et al., 2015; Šumane et al., 2017). It is also argued that the spread of innovation may also be done through farmer networking - whether or not facilitated by formal agricultural knowledge institutions, through collaboration between farmers and researchers as knowledge co-generators, and through multi-actor knowledge networks that bring together participants from various fields. It is suggested by Šumane et al. (2017) that the dynamic contexts, complexity and the local specificity of the current challenges facing agriculture, and the many roles it is being asked to fulfill, require more inclusive, flexible modes of governing the generation, integration and sharing of knowledge. All stakeholders, including farmers, need to be recognised as equal co-authors of knowledge generation, and all kinds of knowledge, both formal and informal, need to be brought together in innovation processes.

The so-called 'openness' of innovation conditionally determines the willingness of innovating together. It overwhelms the spread of the affected area thus giving evidence on both internal and external effects of innovation for local community implementation, especially with regard to distanced social systems in regions with the help of networks. This sometimes also refers to 'responsible innovation', as it is intended to make a positive change for society in the region. Therefore, it becomes evident how important is innovating together - spreading the externally acquired knowledge to local community members when raising its potential to innovate (Duh \& Kos, 2016; Specht, Zoll, \& Siebert, 2016). Local farmers may become a networked driving force for burning and sharing innovations with local community, thus making a tremendous contribution to the development of rural regions and local communities itself.

Therefore, we argue that a better integration of various forms of knowledge could be acquired by networking for innovation, and the potential held by a local farmer might be used for sharing knowledge with the local community to open and accelerate the innovation process. However, it depends on the farmers' state of cooperation with universities and research laboratories when acquiring the brand-new knowledge in the field of farming as a potential to innovate, as well as their willingness to share it with the local community and thus open the innovation process.

The aim of this study is to define the state of innovativeness of Lithuanian farmers in relation to their potential, willingness and conditions to share innovations with local community.

\section{Materials and Methods}

Research approach and methods

Positivist methodology approach has been taken as a basis to organize the research. Scientific literature review, systematization and theoretical modelling methods were used to compose a suitable conceptual framework to measure farmer's innovativeness in the community. Selection of an appropriate conception, which might best serve when taking into account the agrarian discourse-relevant innovation for society in the region dimension, was made using focused review of scientific literature regarding various approaches towards innovations in general and innovations for regional context. Reduction of context-specific material according to the research objective helped distinguish the topical issues in the 'innovating together' dimension of this research.

To ensure the reliability of primary theoretical findings, two-stage exert evaluation was performed. Voluntary team of six international experts in the field, selected using non-probability criterion sampling procedure, helped prove the most suitable approach, dimension and themes for innovating together in agrarian discourse. During the first stage experts rated different approaches towards innovation from most to least suitable to apply in the agrarian 
discourse for defining intents for innovating together. During the second stage rating of separate dimensions from different approaches was done. The calculated Kendall's coefficient of concordance $W$ was close to 1 , thus demonstrating the assessed sufficient agreement among experts. Aggregated expert evaluation results approved the eligibility of primary theoretical findings: the three distinguished themes/key factors of innovating together are suitable to apply for valuing farmers as innovator's intent to innovate together with the local community.

Further analysis helped localize the object-specific category of innovating together with the society in the region. Theoretical modelling encompassed contextspecific adaptation of selected innovative activity routes that are helpful to describe farmer's intent to innovate together with the local community.

Theoretical findings suggested empowering quantitative empirical study to be performed in finding actual evidence for solutions of defined scientific problem. The primary semi-structured interview questionnaire encompassed the two major options for measuring 'innovating together' using the five-point Likert scale. Farmer's intent to innovate together with the local community was defined from the two basic perspectives. First, farmer's activeness in acquiring the necessary potential to innovate and being part of the knowledge sharing network - wider than a region - was defined by option gaining brandnew knowledge from "collaboration with various research laboratories and universities". Second option for innovating together was defined as the farmer's openness when sharing the acquired knowledge and gained experience with the local community.

Pilot face-to-face interviews with 100 Lithuanian farmers were done by a team of scientists. Primary results revealed making insignificant corrections in the formulation of farmer's activities due to the better expressed essence and understanding of the activity.

After implemented corrections, original representative empirical data were collected by experienced research subcontractor. The population of Lithuanian farmers equals to $N=138,9$ thousand (Agriculture and food sector in Lithuania, 2016). The calculated representative population under statistical conditions of $3 \%$ error $(\varepsilon=0.05)$ and $95 \%$ ( $\mathrm{p}=0.5$ ) confidence level is $n=1059$ (Schwarze, 1993). Respondents were selected using systemic sampling of research subcontractors' database. Data were collected using telephone interviews of Lithuanian farmers in January-February 2017. Potential respondents were called 3211 times, 1491 times without response, 612 farmers rejected the suggestion to take part in the interview. Finally, 1108 interviews were acknowledged suitable for further investigations, which satisfied the defined statistical conditions.
The obtained data was processed with descriptive statistical analysis. The percentage distribution of respondents' answers was calculated, comparing data between the groups by using $\chi^{2}$ test (significance level $\mathrm{p}<0.05$ ). The sample size of the study allows ensuring that the statistical error of the results does not exceed $3.1 \%$. Statistical analysis of data was performed using the SPSS 22.0 program. A two-stage variable $\chi^{2}$ independence test was performed to determine whether the respondent's characteristics (sex, age, etc.) affect the distribution of answers to questions. Only those answers were used as evidence, in which the test showed that the distribution of answers depended on the respondents' characteristics.

\section{General sample characteristics}

The interviewed Lithuanian farmers represent all the municipalities of the country, different natural areas reflect various farming conditions and the corresponding characteristics of farmers and farms: the gender, age, education of the farmer; the size of farm, duration of farming activity, and type of farming (Agriculture and food sector in Lithuania, 2015).

The study involved $57.7 \%$ men and $42.3 \%$ women. The majority of surveyed farmers $(38.3 \%)$ were respondents aged from 55 to 64; the second age group $(27.6 \%)$ were farmers aged between 45 and 54 , respondents of 65 years and older composed $23.9 \%$. The smallest group of respondents was represented by the youngest farmers: 1.1 percent is up to 35 years old and $9.1 \%$ aged between 35 and 44 . The majority of respondents (34.5\%) had acquired professional education; farmers with acquired upper and secondary education composed respectively $23.7 \%$ and $21.4 \%$. The smallest group of respondents according to their education consisted of respondents with lower secondary $(4.6 \%)$ and primary education (1.6\%). The majority $(88.4 \%)$ of the surveyed farmers acquired education before 1990 (or in the Soviet period), 10 percent - before the Lithuania's accession to the EU (i.e. in the period of $1990-2004$ ) and $1.6 \%$ in 2005 or later, i.e. after Lithuania's accession to the EU.

Less than half of the surveyed farmers (40.2\%) have a farm of economic size (turnover in euros per month) up to EUR 4,000 and, according to this criterion, falls into the smallest group of farms. $22.3 \%$ of respondents' farms has the turnover from EUR 4,001 to 8,$000 ; 16.3 \%$ - from EUR 8,001 to 15,$000 ; 8.8 \%$ from EUR 15,001 to 25,000; 6.3\% - from EUR 25,001 to 50,000. The smallest group of respondents consists of the farms with the largest turnover. The turnover of the surveyed companies ranges as follows: $3.4 \%$ - from EUR 50,001 to 100,000, 1.9\% - from EUR 100,001 to 250,000 and $0.8 \%$ - more than EUR 250,001. The majority of respondents $(44.8 \%)$ are farmers whose farm size is up to 20 ha; $32.1 \%$ - from 20.1 to 50 ha; 
$13.7 \%$ - from 50.1 to 100 ha. The smallest part of the respondents are farmers with farms of 100.1 to 500 ha $(9.2 \%)$ and more than 500.1 ha $(0.2 \%)$.

According to the criterion of the duration of the activity, almost half of the surveyed farmers (46.6\%) started their farming activities 21 years ago or even earlier, a similar proportion of respondents (43.1\%) from 11 to 20 years ago, and the youngest farms with experience of 10 and less years of farming composed $10.3 \%$. More than half of the respondents $(54.1 \%)$ have mixed (both crop and livestock) farms, $21.5 \%$ are crop farmers, and livestock farmers compose $13.3 \%$. By summarizing the general characteristics of survey respondents, it can be stated that the survey data is representative.

\section{Results and Discussion}

The evidence obtained through interviewing farmers helps prove the theoretically composed framework of innovating together. First of all, the collected structured data help define the state of technical (production facilities) and organizational (farm organizational processes) innovations in Lithuanian farms and the intensity of farmer's attention with regard to these innovations. Secondly, the measured intent to acquire new knowledge and experience through collaboration with research laboratories and universities, and willingness to share this knowledge and experience with the local community help define the shift from sectorial to territorial strategies in the name of local community involvement in the innovation process. The third analysed defining factor was the size of farms and operating units to demonstrate the potential to innovate. Altogether, these factors help identify whether Lithuanian farmers hold conditions and potential, as well as willingness to innovate together with the local communities.

The state of technical and organizational innovations

The interviewed farmers were asked, how often they upgrade the existing production facilities and how often they purchase modern production facilities in their farms, ranging from less than once a year, once a year or more often than once a year.

Research results demonstrate (Figure 1) that Lithuanian farmers are equally passive innovators.

The upgrade of the existing production facilities took the dominant position, represented by $76.1 \%$ of respondents, who said they do it is less than once a year. Organizational processes are also very rarely upgraded $-85.2 \%$ of the interviewed farmers said they do this less than once a year. The question concerning the purchasing of modern production facilities was mentioned as performed rarer than once a year by $90.2 \%$ of the respondents. Installing innovative organizational processes less than once a year is done by $84.3 \%$ of Lithuanian farmers. Going deeper into the detailed descriptive analysis of the research results, it becomes evident that among those farmers who responded that they perform the listed innovative activities 1 time per year and more than 1 time per year, are experienced farmers who hold the farm for 11 and more years. Due to the three distinguished types of farming, research results show that innovations are more acceptable to be installed and applied in mixed farms $(56.8 \%)$, than in crop farming $(25.5 \%)$ and the last position is taken by livestock farms $(17.7 \%)$. It was an unexpected finding that the bigger the farm is due to its annual turnover, the less active it is in

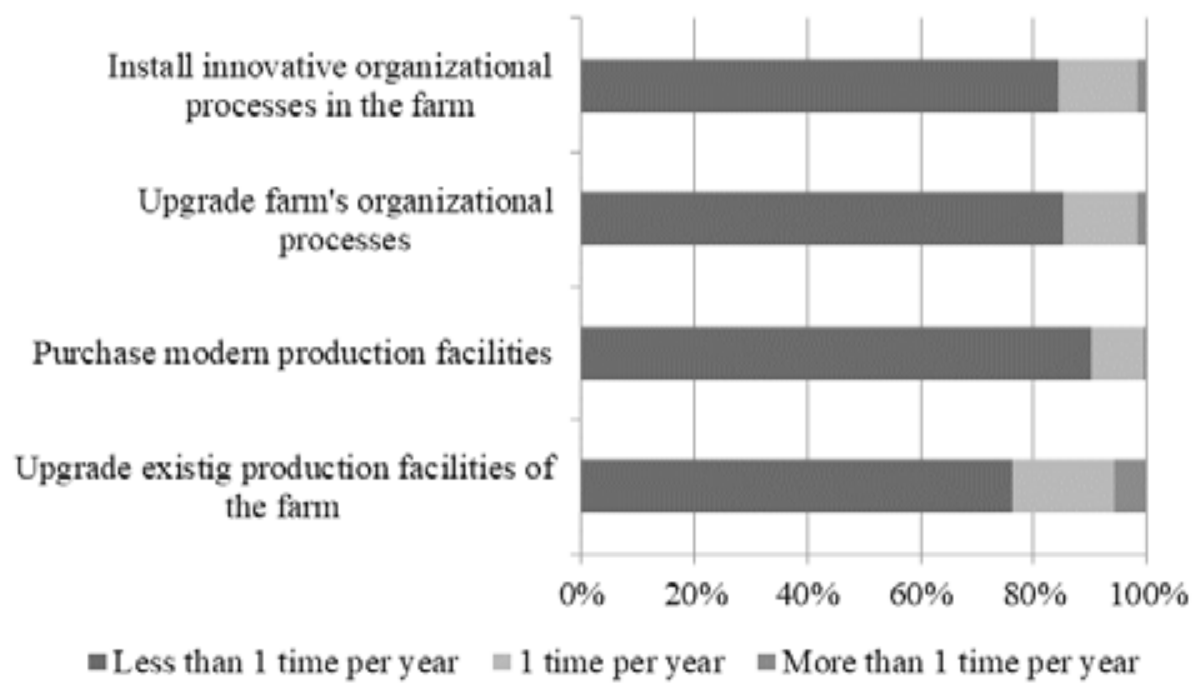

Source: authors' calculations.

Figure 1. The intensity of upgrading and installing facilities and organizational processes as innovations in the Lithuanian farms. 
Frequency of farmers' intent to acquire new knowledge for innovation and share it with local community

\begin{tabular}{|c|c|c|}
\hline & $\begin{array}{c}\text { Collaboration with various research } \\
\text { laboratories and universities, valid percent }\end{array}$ & $\begin{array}{c}\text { Sharing the acquired knowledge and experience } \\
\text { with the local community, valid percent }\end{array}$ \\
\hline Never & 65.3 & 36.7 \\
\hline Very rare & 9.4 & 9.0 \\
\hline Rare & 13.6 & 18.3 \\
\hline Often & 8.3 & 26.3 \\
\hline Constantly & 3.4 & 9.7 \\
\hline Total & 100 & 100 \\
\hline
\end{tabular}

Source: authors' calculations.

upgrading its equipment and processes. The same situation was seen with purchasing new equipment and installing innovative organizational processes. It became evident from this point of view that most active innovators both from technical to organizational innovations are farms with the turnover of up to EUR 50,000. Research results reveal that most active innovators are aged between 45 and 65 .

The potential to shift from sectorial to territorial rural development strategies

The potential to shift from sectorial to territorial rural development strategies is defined using the two core parameters for 'innovating together': first, collaboration with various research laboratories and universities; and second, sharing knowledge and experience with the local community. Aggregated research results are presented in Table 1 .

Research findings demonstrate that in total only $11.7 \%$ of farmers constantly $(3.4 \%)$ and often
$(8.3 \%)$ collaborate with the research laboratories and universities as the potential sources for new knowledge and skill acquisition and take part in networking for innovation. The rest of the farmers demonstrate passive attitude towards innovation process. In contrast to that, sharing gained experience and knowledge with the local community was a more favourable option. Over one third of Lithuanian farmers constantly or often share their knowledge and experience with the local community and this shows a greater potential for spreading innovation. On the other hand, the knowledge and experience, which has a positive tendency to be shared with the local community, seems to be based on individual achievements and development rather than gathered through collaboration with advanced research institutions and excellence centres. Most disappointing results arrive from those who never collaborate $(65.3 \%$ !) and never share $(36.7 \%)$ any knowledge and experience. It means that a huge number of farmers have no intention to innovate both

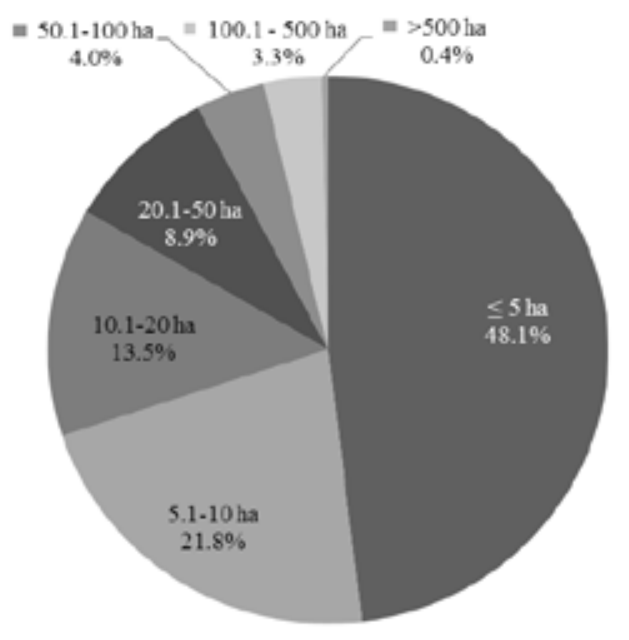

Source: Agriculture and Food sector in Lithuania 2016.

Figure 2. Structure of farms by declared agricultural area in Lithuania in 2016, in percent. 
apart or together. However, the intention to innovate apart is less distinct than the intention to innovate together.

Structure of farm size and rural enterprises in Lithuania

The above implemented theoretical analysis revealed that the structure of farm size is interrelated to the number of employees and, accordingly, to the potential to innovate. Therefore, analysis of the structure of farm size and rural enterprises might add to the analysis of 'innovating together' and help disclose the potential to innovate, arriving from the inside of a farm.

Small farms dominate in Lithuania. Most of Lithuanian farms and rural enterprises have a small number of employees. Analysis of structure of farms by the declared agricultural area in Lithuania in 2016 demonstrates this tendency. In 2016, according to the area declared by all agricultural entities, the average farm size in Lithuania was 21.2 ha. In 2016, the share of farms with the farm size less than 5 ha, was $48.1 \%$ (see Figure 2). A large share of $21.8 \%$ also belong to the farms with the farm size between 5 and 10 ha. Thus in Lithuania in 2016 almost 70 percent of all farms were small farms with the farm size less than 10 ha.

This situation explains why the cooperation and networking is so important for small farms in Lithuania. Farmers of such farms should focus on the implementation of the collaboration strategy, use various two-sided networks and their platforms to start close cooperation between farmers and users of their products - their customers.

\section{Conclusions}

Current economic and social situation of rural regions encourages rural population to create new perceptions in farming and rural life based on new success factors and ability to innovate. The shift from technical to organizational innovations dealing with changes of managerial and marketing processes in farming have occurred. Farmers and rural communities that focus on innovation as a core value usually result in successful business or community activities. Networking is perceived as an important strategic tool in attaining innovation.

The potential of 'innovating together' calls for collective actions via networking, which might help accelerate the access and acquisition to brand new knowledge as well as spreading these ideas for community in the region, which in total would lead to opening the innovation. 'Innovating together' might come into action in case of existence of the three main factors: first, the shift from technical to organizational innovations; second, the shift from sectorial to territorial rural development strategies; and third, the size of farms and rural enterprises due to the limited number of employees.

Empirical investigations suggest several important insights. First, the state of technical (production facilities) and organizational (farm organizational processes) innovations in Lithuanian farms demonstrate low farmer's attention as well as inputs with regard to these innovations. Second, the measured intention to acquire new knowledge and experience through collaboration with research laboratories and universities and willingness to share this knowledge and experience with the local community defined the non-existence of the shift from sectorial to territorial strategies in the name of local community involvement in innovation process. And third, the domination of small farms in Lithuania leads to the usage of cooperation and networking as tools for successful way of their activity. Farmers of small farms should focus on the implementation of the collaboration strategy, on using various two-sided networks and their platforms to start close cooperation between farmers and users of their products. Altogether, these factors help identify weak potential of Lithuanian farmers as well as willingness to innovate together with local communities.

\section{Acknowledgements}

Data for this research was collected during the implementation of scientific research project funded by a grant (No. MIP-098/2015) from the Research Council of Lithuania.

\section{References}

1. Agriculture and Food sector in Lithuania in 2015 (2016). Lithuanian Institute of Agrarian Economics. Vilnius, 2016.

2. Agriculture and Food sector in Lithuania in 2016 (2017). Lithuanian Institute of Agrarian Economics. Vilnius, 2017.

3. Cho, O. (2017). How Migrants from Cities Become Potential Innovators in Korean Rural Communities. Journal of Asian Rural Studies, 1(1), 13-18.

4. Chrisman, J.J., Chua, J.H., De Massis, A., Frattini, F., \& Wright, M. (2015). The ability and willingness paradox in family firm innovation. Journal of Product Innovation Management, 32(3), 310-318.

5. Creaney, R., McKee, A., \& Prager, K. (2014). Designing, implementing and maintaining (rural) innovation networks to enhance farmers' ability to innovate in cooperation with other rural actors. Monitor Farms in 
Scotland, UK. Report for AKIS on the ground: focusing knowledge flow systems (WP4) of the PRO AKIS project.

6. Duh, E.S., \& Kos, A. (2016, October). Fablabs as Drivers for Open Innovation and Co-creation to Foster Rural Development. In Identification, Information and Knowledge in the Internet of Things (IIKI), 2016 International Conference on (pp. 214-216). IEEE.

7. Dunne, T.C., Aaron, J.R., McDowell, W.C., Urban, D.J., \& Geho, P.R. (2016). The impact of leadership on small business innovativeness. Journal of Business Research, 69(11), 4876-4881.

8. Esparcia, J. (2014). Innovation and networks in rural areas. An analysis from European innovative projects. Journal of Rural Studies, 34, 1-14.

9. Friedrich von den Eichen, S., Freiling, J., \& Matzler, K. (2015). Why business model innovations fail. Journal of Business Strategy, 36(6), 29-38, DOI: 10.1108/JBS-09-2014-0107.

10. Griffin, R. (2013). Fundamentals of management, Cengage Learning. Inc., Florence, KY.

11. Jean, B. (2014). A new paradigm of rural innovation: learning from and with rural people and communities. 54th Congress of the European Regional Science Association: "Regional development \& globalisation: Best practices”, 26-29 August 2014, St. Petersburg, Russia.

12. Kusano, S., Wright, M., \& Conger, A. (2016). Development and assessment of self-agency, and the ability to innovate and take risks. Center for Research on Learning and Teaching Occasional Paper, 34.

13. Lambrecht, E., Taragola, N., Kühne, B., Crivits, M., \& Gellynck, X. (2015). Networking and innovation within the ornamental plant sector. Agricultural and Food Economics, 3(1), 10.

14. Madureira, L., Koehnen, T., Ferreira, D., Pires, M., Cristóvão, A., Baptista, R., McKee, A., Prager, K., Creaney, R., Caggiano, M., Boenning, K., \& Knierim, A. (2015). Designing, implementing and maintaining agricultural/rural networks to enhance farmers' ability to innovate in cooperation with other rural actors. Final Synthesis Report for AKIS on the ground: focusing knowledge flow systems (WP4) of the PRO AKIS.

15. Neumeier, S. (2017). Social innovation in rural development: identifying the key factors of success. The geographical journal, 183(1), 34-46, DOI: 10.1111/geoj.12180.

16. Pittaway, L., Robertson, M., Munir, K., Denyer, D., \& Neely, A. (2004). Networking and innovation: a systematic review of the evidence. International journal of management reviews, 5(3-4), 137-168, DOI: 10.1111/j.1460-8545.2004.00101.x.

17. Reimers-Hild, C.I., \& Dye, A. (2015b). How to Grow Your Rural Business with Purpose and Meaning.

18. Reimers-Hild, C., \& Dye, A. (2015a). Become a Future-Focused Leader: Use Three Megatrends to Grow Your Rural Business.

19. Salemink, K., Strijker, D., \& Bosworth, G. (2017). Rural development in the digital age: A systematic literature review on unequal ICT availability, adoption, and use in rural areas. Journal of Rural Studies, 54, 360-371, DOI: 10.1016/j.jrurstud.2015.09.001.

20. Schwarze, J. (1993). Grundlagen der Statistik 2. (Basics of Statistics 2). Herne/Berlin: Neue Wirtschaftsbriefe. (in German).

21. Specht, K., Zoll, F., \& Siebert, R. (2016). Application and evaluation of a participatory "open innovation" approach (ROIR): The case of introducing zero-acreage farming in Berlin. Landscape and Urban Planning, 151, 45-54.

22. Šūmane, S., Kunda, I., Knickel, K., Strauss, A., Tisenkopfs, T., des Ios Rios, I., Rivera, M., Chebach, T., \& Ashkenazy, A. (2017). Local and farmers' knowledge matters! How integrating informal and formal knowledge enhances sustainable and resilient agriculture. Journal of Rural Studies, DOI: 10.1016/j. jrurstud.2017.01.020.

23. Vaccaro, I.G., Jansen, J.J., Van Den Bosch, F.A., \& Volberda, H.W. (2012). Management innovation and leadership: The moderating role of organizational size. Journal of Management Studies, 49(1), 28-51, DOI: 10.1111/j.1467-6486.2010.00976.x.

24. Vidickienè, D. (2017). Economic Regulation Directions Regarding the Essential Shift in the Structure of Economy. Viesoji Politika ir Administravimas, 16(3).

25. Zago, R., Block, T., Dessein, J., Brunori, G., \& Messely, L. (2015). Citizen participation in neo-endogenous rural development: the case of LEADER programme. In 6th EAAE PhD workshop, co-organized by AIEAA (Italian Association of Agricultural and Applied Economics) and the Department of Economics of Roma Tre University. European Association of Agricultural Economists (EAAE). 